\title{
Estimating 30-year change in coastal old-growth habitat for a forest-nesting seabird in British Columbia, Canada
}

\author{
Jed A. Long ${ }^{1, *}$, Stephanie L. Hazlitt ${ }^{2}$, Trisalyn A. Nelson ${ }^{1}$, Karen Laberee ${ }^{1}$ \\ ${ }^{1}$ Spatial Pattern Analysis \& Research Lab, Department of Geography, University of Victoria, PO Box 3060, \\ Victoria, British Columbia V8W 3R4, Canada \\ ${ }^{2}$ Ecosystems Branch, British Columbia Ministry of Environment, PO Box 9338, Station Provincial Government, \\ Victoria, British Columbia V8W 9M1, Canada
}

\begin{abstract}
The marbled murrelet Brachyramphus marmoratus is an old-growth dependent species that nests in North American coastal forests. Canadian populations and occurrence data are limited; however concern over loss of nesting habitat in coastal British Columbia led to an assessment of 'threatened' by the Committee on the Status of Endangered Wildlife in Canada, and subsequent listing under the Canadian Species at Risk Act. Information on the availability and patterns of change in nesting habitat is essential for making land-use decisions and for monitoring the conservation status of this wide-ranging seabird. We estimated potential marbled murrelet nesting habitat for the coast of British Columbia at 2 points in time, 1978 and 2008, and quantified habitat loss and modelled habitat recruitment over this $30 \mathrm{yr}$ time period, a key time frame for the assessment of the conservation status of this high-profile species. We implemented 3 predictive habitat suitability models for the province of British Columbia, ranging from exclusive to more inclusive models. Based on the various habitat model scenarios, including corrections using aspatial harvest records, we estimated that 20 to $24 \%$ of potential marbled murrelet nesting habitat was lost to forest harvest and fire from 1978 to 2008. If modelled habitat recruitment is considered, then net change in potential nesting habitat is 20 to $22 \%$ loss. Our estimates of potential murrelet habitat and subsequent habitat loss and change are influenced by numerous sources of uncertainty, such as actual suitability of forest stands for breeding murrelets and known deficiencies in the forest harvest spatial datasets. However, the results presented here provide the first range of province-wide habitat change possibilities and are consistent with previous regional analyses of potential marbled murrelet habitat loss in British Columbia.
\end{abstract}

KEY WORDS: Marbled murrelet $\cdot$ Brachyramphus marmoratus $\cdot$ Nesting habitat $\cdot$ Spatial modelling · Habitat loss · British Columbia · Geographic information systems · GIS

\section{INTRODUCTION}

Marbled murrelets Brachyramphus marmoratus are small seabirds that live along the northern Pacific coast of North America. Unlike typical members of the Alcidae family, marbled murrelets nest primarily in the trees of coastal old-growth forests (Burger 2002, Piatt et al. 2007). The distribution of marbled murrelets ranges from northern California to Alaska, with larger murrelet populations found at higher latitudes and the majority of the global population found in Alaska (Piatt et al. 2007). It is estimated that British Columbia, the sole range of breeding marbled murrelets in Canada, is home to approximately 99600 marbled murrelets (72600-125600, Bertram et al. 2007). Details of the spatial distribution of the murrelet population within British Columbia are limited; marine environments have not been systematically surveyed across the 
province (but see Yen et al. 2004), and their cryptic nesting behaviour makes them difficult to study, especially in remote terrestrial locations (Canadian Marbled Murrelet Recovery Team, CMMRT 2003). While marine surveys, along with historical anecdotes of abundance, have suggested a sharp decline in marbled murrelet populations in some areas, other data suggest some stable populations in British Columbia (e.g. Kelson et al. 1995, Burger 2002, Lank et al. 2003, Piatt et al. 2007). However, historical information on the number of marbled murrelets in British Columbia and population or demographic data are limited for this elusive species (CMMRT 2003).

The Canadian population of marbled murrelets was assessed as 'threatened' by the Committee on the Status of Endangered Wildlife in Canada (COSEWIC 2000), resulting in the legal listing of the marbled murrelet under the Canadian Species at Risk Act. With limited information on population status (e.g. decline of mature individuals), the Canadian marbled murrelet conservation assessment was based on an estimated reduction in the extent of old-growth forest nesting habitat in coastal British Columbia over approximately $30 \mathrm{yr}$, or 3 generations, a standardised time window for species conservation assessments (COSEWIC 2000, IUCN Standards and Petitions Subcommittee 2010). Loss of terrestrial nesting habitat is considered the primary threat to marbled murrelet populations rangewide (CMMRT 2003, Piatt et al. 2007) and is well supported by the literature (e.g. Burger 2001, 2002, Raphael et al. 2002, Piatt et al. 2007, Burger \& Waterhouse 2009). Other threats to population persistence occur in the marine environment, including fisheries by-catch and oil spills (CMMRT 2003). In addition, recent research has highlighted the potential role of historical depletion of food supply (i.e. fisheries) in marbled murrelet declines and/or the potential for population recovery (e.g. Becker \& Beissinger 2006, Becker et al. 2007, Beissinger \& Peery 2007, Norris et al. 2007, Gutowsky et al. 2009).

Marbled murrelet nesting habitat has been well characterised at landscape, stand, tree and platform levels (e.g. Burger 2002, Piatt et al. 2007, Burger et al. 2010). Marbled murrelet nests are typically found in trees with large branches and sufficient epiphytic growth (e.g. Burger et al. 2010), characteristics that are usually found in relatively older and taller trees (e.g. $>250 \mathrm{yr}_{1}>28.5 \mathrm{~m}$ high, Burger 2002). Associations of nest sites with other macro-habitat features, such as elevation and distance to sea, have also been investigated in order to characterise suitable habitat over increasing scales (Burger 2002). Nest trees are generally found up to $50 \mathrm{~km}$ inland, but mostly within $30 \mathrm{~km}$ from the shoreline (Burger 2002), as these seabirds are limited by the commuting distance from foraging areas (Hull et al. 2001).
Quantifying the degree of change in available marbled murrelet old-growth nesting habitat through time is necessary for characterising present, and predicting future abundance of marbled murrelets in British Columbia, assuming that terrestrial habitat is a key predictor of population abundance and an indicator of the likelihood of local population persistence (e.g. Burger 2001, Steventon et al. 2003, Burger \& Waterhouse 2009). Recent research efforts have produced regional- and broad-scale estimates of potential murrelet nesting habitat for single time periods (e.g. Waterhouse et al. 2008, 2009, Mather et al. 2010), as well as a few regional-scale or shorter time-frame analyses estimating change in available murrelet habitat (e.g. Gowgaia Institute 2007, M. Tomlins \& M. Gray unpubl.).

Here we used geographic information systems (GIS) and habitat suitability modelling techniques to implement a set of 3 spatially explicit, province-wide terrestrial marbled murrelet habitat models. We also estimated the amount of forest disturbance from forest harvest and fires, and resulting change in availability of predicted marbled murrelet nesting habitat over a $30 \mathrm{yr}$ period for the entire coast of British Columbia. We mapped forest conditions in 2 time periods, 1978 and 2008; applied 3 predictive marbled murrelet nesting habitat suitability models to estimate the amount of nesting habitat available for the years 1978 and 2008, quantified the amount of loss from forest harvest and fire; and finally, calculated net change, assuming modelled recruitment of suitable nesting habitat between 1978 and 2008. The results presented here provide the first province-wide account of spatially explicit habitat change scenarios, and we discuss the benefits and limitations of a spatially explicit approach for deriving estimates of species habitat change over large areas.

\section{MATERIALS AND METHODS}

Study area. The study area includes the entire coast of British Columbia, the current range of the breeding population of marbled murrelets in Canada (CMMRT 2003). The study area is divided into 6 conservation regions of different sizes: West and North Vancouver Island (2.15 million ha); East Vancouver Island (1.15 million ha); Southern Mainland Coast (3.97 million ha); Central Mainland Coast (4.21 million ha); Northern Mainland Coast (5.61 million ha); and Haida Gwaii (1 million ha; Fig. 1). These regions were developed by the CMMRT and are based on forest districts, land and wildlife management regions, and ecosection boundaries (CMMRT 2003). Each conservation region differs in the current estimated abundance of marbled murrelets and in conservation priorities (CMMRT 2003). 


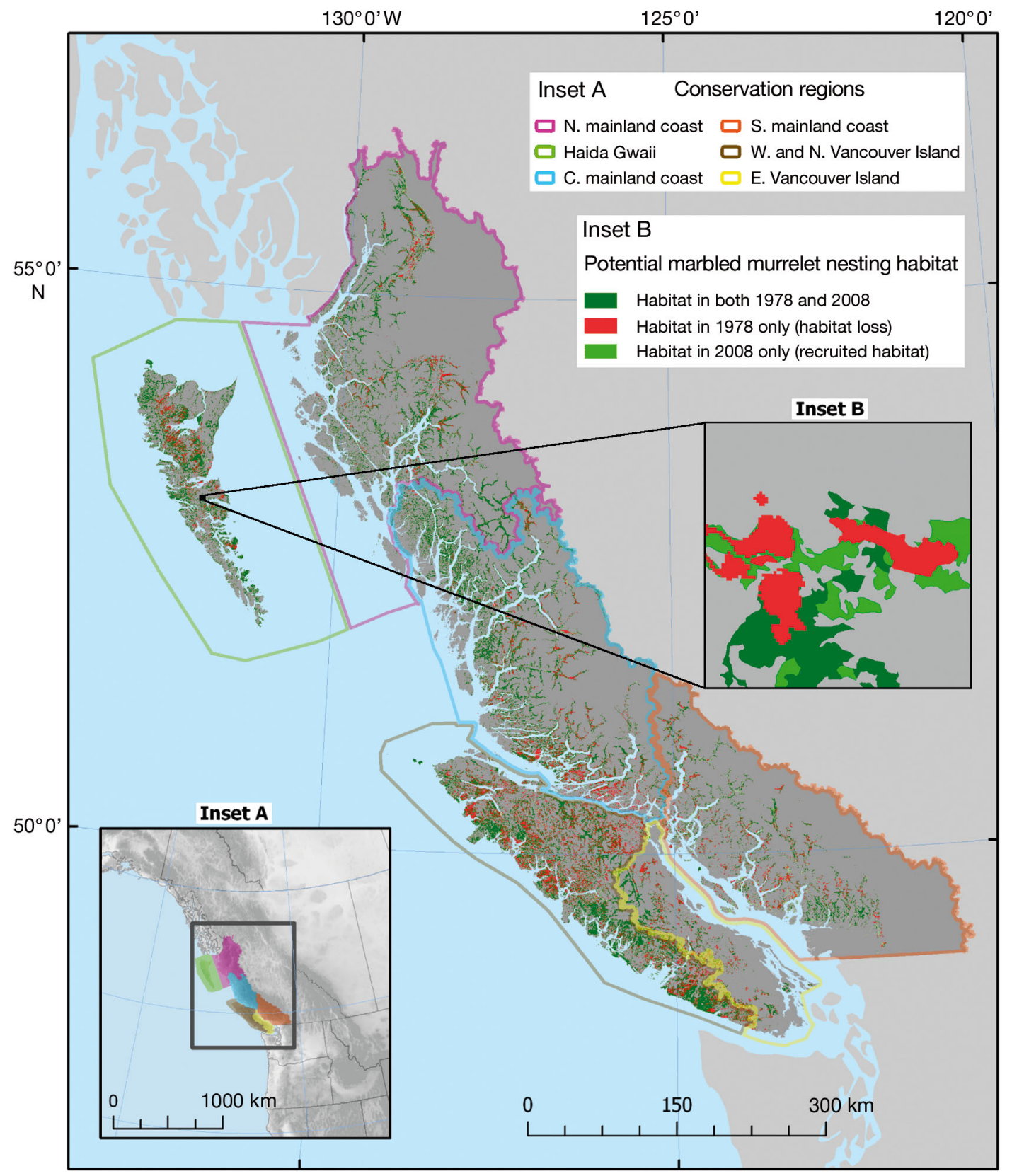

Fig. 1. Six conservations regions for management of old-growth marbled murrelet Brachyramphus marmoratus nesting habitat in British Columbia (Inset A), with results from analysis of changes in potential nesting habitat area (main map) using the intermediate (Model 2) definition of habitat. Example of detailed view of habitat results provided in Inset B

Marbled murrelet nesting habitat model selection. Several predictive attributes and models of potentially suitable marbled murrelet nesting habitat have been developed for British Columbia (e.g. McLennan et al. 2000, Bahn \& Newsom 2002, CMMRT 2003, Chatwin \& Mather 2007, Mather et al. 2010). All predictive habitat models carry some degree of uncertainty, due, for example, to limited or poor quality input data (e.g. Waterhouse et al. 2010). In an attempt to account for the influence of model uncertainty, we implemented
3 predictive marbled murrelet habitat suitability models. The 3 models reflect a range of predictive scenarios of potential marbled murrelet nesting habitat from an exclusive model (Model 1; CMMRT 2003), an intermediate model (Model 2; Mather et al. 2010), to an inclusive model (Model 3; CMMRT 2003). All 3 models use 4 key environmental variables (forest height, forest age, elevation and distance from nearest ocean shoreline; Table 1), which are appropriate for large-area modelling of potential marbled murrelet nesting habitat. 
Table 1. Marbled murrelet nesting habitat attributes for each of 3 habitat suitability models. Model 1 is the most exclusive, Model 2 is intermediate, and Model 3 is the most inclusive, in terms of definition of potential marbled murrelet nesting habitat

\begin{tabular}{|lccc|}
\hline Attributes & Model 1 & Model 2 & Model 3 \\
\hline Forest stand age (yr) & $\geq 250$ & $\geq 140$ & $\geq 140$ \\
Forest stand height (m) & $\geq 28.5$ & $\geq 28.5$ & $\geq 19.5$ \\
Distance to ocean & $0.5-30$ & $0-50$ & $0-50$ \\
$\quad$ shoreline (km) & & & \\
Elevation (m) & & & \\
$\quad$ Central \& Northern & $\leq 600$ & $\leq 600$ & $\leq 900$ \\
$\quad$ Mainland Coast & & & \\
$\quad$ Haida Gwaii & $\leq 500$ & $\leq 500$ & $\leq 800$ \\
All other regions & $\leq 900$ & $\leq 900$ & $\leq 1500$ \\
\hline
\end{tabular}

Model 1, based on guidelines developed by the CMMRT (2003), uses the most exclusive definition of potential marbled murrelet nesting habitat. Model 1 is equivalent to the CMMRT's estimate of 'most likely' habitat, where habitat is considered potential marbled murrelet nesting habitat if forest age is $\geq 250 \mathrm{yr}$, forest height is $\geq 28.5 \mathrm{~m}$, and location is $500 \mathrm{~m}$ to $30 \mathrm{~km}$ from ocean shorelines. Elevation thresholds vary from $\leq 500 \mathrm{~m}$ to $\leq 900 \mathrm{~m}$ and depend on conservation region (Table 1). Model 1 indicates potential habitats considered most likely to provide suitable nesting habitat for marbled murrelets in British Columbia (CMMRT 2003).

Model 2 is the most common set of parameters used for estimating potential marbled murrelet nesting habitat in coastal British Columbia (Chatwin \& Mather 2007, Mather et al. 2010, Waterhouse et al. 2010). Model 2 uses the attribute thresholds from Mather et al. (2010), which are based on a hybrid of the CMMRT's predicted 'most and moderately likely' guidelines for habitat attributes (CMMRT 2003). In this case, nesting habitat is modelled as locations with forests aged $\geq 140 \mathrm{yr}$, heights $\geq 28.5 \mathrm{~m}$, and distance to ocean shoreline between 0 and $50 \mathrm{~km}$ (Table 1). Elevation classes associated with Model 2 are the same as with Model 1.

Model 3 employs the most inclusive definition of potential marbled murrelet nesting habitat, with a location considered potential marbled murrelet nesting habitat if it meets the requirements of the CMMRT's (2003) model for either 'most likely' or 'moderately likely' habitat. Forest age is $\geq 140 \mathrm{yr}$, forest height is $\geq 19.5 \mathrm{~m}$, and location is 0 to $50 \mathrm{~km}$ from ocean shorelines. Elevation thresholds in Model 3 are higher than other models and range from $\leq 800$ to $\leq 1500 \mathrm{~m}$ depending on conservation region (Table 1). Given the inclusivity of this parameter set, the recovery team recommended detailed ground-truthing of 'moderately likely' habitats to ensure that these habitats contain the potential attributes required for nesting marbled murrelets (CMMRT 2003).

Data sources. The distance-to-ocean-shoreline variable was computed using British Columbia's baseline thematic mapping (BTM) data (British Columbia Ministry of Environment, Lands and Parks 1995). This dataset was derived using visual interpretation of Landsat satellite imagery from the early and mid-1990s and provides a coarse definition of British Columbia land cover and coastline. Included in this dataset is a saltwater map, from which distance-to-ocean-shoreline calculations were made. Using the BTM data, deep inlets, which occur regularly along the coast of British Columbia, are considered saltwater and were used in distance-to-ocean-shoreline calculations.

Elevation was determined using a digital elevation model (DEM), with a spatial resolution of $25 \mathrm{~m}$. This DEM was created from 1:20000 Terrain Research Information Management data (Province of British Columbia 1996) and is reported to be accurate within $10 \mathrm{~m}$ (British Columbia Ministry of Sustainable Resource Management 2002).

In British Columbia, the most complete dataset for mapping forest age and height variables is the forest inventory, which contains detailed age and height information on forest stands, is spatially continuous, and covers $90 \%$ of our study area. Regions excluded from the forest inventory data include privately owned timber land holdings, such as those along the southeast coast of Vancouver Island, as well as some park lands. Polygons, the spatial unit of the forest inventory, are used to represent forest stands (Leckie \& Gillis 1995) and are commonly selected as the spatial unit for modelling marbled murrelet habitat over broad spatial scales (e.g. Chatwin \& Mather 2007, Mather et al. 2010). In constructing the forest inventory, forest stand attributes were visually interpreted from aerial photographs. Stand age is the average age, in years, of the dominant and co-dominant trees in a forest stand and is typically estimated indirectly from aerial photographs. Stand ages are recorded as individual years, but also grouped into categories: 1-20, 21-40, 41-60, $61-80,81-100,101-120,121-140,141-250$, and > $250 \mathrm{yr}$. Interpretation of individual stand age becomes increasingly difficult as forests reach maturity; as such, category midpoints are often assigned as the forest age for the individual year attribute (Wong et al. 2003). We used individual stand age in our analysis. Stand height was interpreted directly from the aerial photograph and reported in metres.

For the remaining $10 \%$ of the study area, where forest inventory data are unavailable, BTM data (British Columbia Ministry of Environment, Lands and Parks 1995) were used. BTM data provide broad information 
on stand age, reported as age categories: old forest (>140 yr), young forest (20-140 yr) and recently harvested $(<20 \mathrm{yr})$. Height variables are unavailable with the BTM data, but it was assumed that old forest stands were also of suitable height for marbled murrelet nesting habitat.

Sources of change to potential marbled murrelet nesting habitat. Since our goal was to estimate change in potential marbled murrelet habitat between 1978 and 2008, we required data for each environmental variable at each time period. Distance to ocean shoreline and elevation do not change between time periods. As forest stands age, height growth slows, reaching a constant once mature (Ryan \& Yoder 1997). Given the broad height classes used in marbled murrelet habitat modelling, height changes have little impact on model estimates and therefore were treated as static in the analysis. Forest stand ages were modelled dynamically, changing stand age appropriately from 1978 to 2008.

Forest disturbances, including those from both anthropogenic (e.g. harvest) and natural (e.g. fire) causes, represent the primary sources of loss to potential marbled murrelet nesting habitat (CMMRT 2003). The forest inventory and BTM datasets have not been judiciously updated and are missing many forest disturbances from 1978 to 2008. Thus, it was necessary to look to other data sources to obtain complete forest disturbance records. Spatially explicit forest disturbance data are available from a variety of data sources (Table 2). Due to known deficiencies (both spatial and temporal), we complemented the available forest disturbance data with a Landsat-based change detection method using the enhanced wetness difference index (EWDI). The EWDI is based on the wetness component of the tasselled cap transformation and can be used to spatially identify large forest disturbances (Franklin et al. 2001, 2002). We restricted our analysis to those disturbances $>1$ ha to align with existing disturbance datasets (A. Morrison pers. comm.). All forest disturbance data (Table 2) were combined to create a single, spatially explicit forest disturbance dataset for 1978 to 2008.

Landsat imagery is unavailable prior to 1985 and thus our method using Landsat imagery to fill in gaps could not be used from 1978 to 1985 . We therefore drew upon aspatial harvest records for 1978 to 1985 to improve our calculation of forest disturbance and subsequent estimates of potential marbled murrelet nesting habitat loss.

Estimating change in modelled nesting habitat. We combined the forest inventory data with forest disturbance data using appropriate GIS operations (Fig. 2) to derive forest attribute datasets for 1978 and 2008 . Forest attribute data for 1978 and 2008 are combined with distance-to-ocean-shoreline and elevation data to implement the 3 marbled murrelet nesting habitat models (Fig. 2).

When forest age is included in a habitat model, there are 2 approaches to modelling habitat loss. Habitat loss can be modelled as the amount of habitat observed in the initial time period (1978) minus the amount of habi-

Table 2. Data sources used in derivation of 1978 and 2008 potential marbled murrelet nesting habitat. See Fig. 2 for a flow diagram demonstrating how all datasets are integrated into the analysis. BC: British Columbia, TFL: tree farm licence

\begin{tabular}{|c|c|c|}
\hline Dataset & Notes & Source \\
\hline Forest inventory & $\begin{array}{l}\text { Primary source of forest attribute } \\
\text { information }\end{array}$ & $\begin{array}{l}\text { BC Ministry of Forests and Range, Forest } \\
\text { Analysis and Inventory Branch, Victoria, BC }\end{array}$ \\
\hline $\begin{array}{l}\text { Baseline thematic } \\
\text { mapping (BTM) }\end{array}$ & $\begin{array}{l}\text { Used in distance to ocean shoreline calcu- } \\
\text { lation and to supplement forest inventory }\end{array}$ & $\begin{array}{l}\text { BC Ministry of Environment, Lands and Parks, } \\
\text { currently housed with GeoBC, Integrated } \\
\text { Land Management Bureau, Victoria, BC }\end{array}$ \\
\hline $\begin{array}{l}\text { British Columbia digital } \\
\text { elevation model (DEM) }\end{array}$ & Elevation data (25 m resolution) & $\begin{array}{l}\text { BC Ministry of Sustainable Resource Management, } \\
\text { Base Mapping and Geomatics Services Branch, } \\
\text { Victoria, BC }\end{array}$ \\
\hline \multicolumn{3}{|l|}{ Forest disturbance data } \\
\hline $\begin{array}{l}\text { Vegetation Resources } \\
\text { Inventory (VRI) }\end{array}$ & $\begin{array}{l}\text { Available for 1978-2008, primary } \\
\text { harvest data }\end{array}$ & Sandvoss et al. (2005) \\
\hline RESULTS database & $\begin{array}{l}\text { Available for 1980-2008, harvest } \\
\text { data for TFLs }\end{array}$ & $\begin{array}{l}\text { BC Ministry of Forests and Range, Forest Analysis } \\
\text { and Inventory Branch, Victoria, BC }\end{array}$ \\
\hline $\begin{array}{l}\text { Change detection layer } \\
\text { (CDL) }\end{array}$ & $\begin{array}{l}\text { Available for } 2000-2008 \text {, harvest data } \\
\text { for private lands (>1 ha) }\end{array}$ & $\begin{array}{l}\text { BC Ministry of Forests and Range, Forest Analysis } \\
\text { and Inventory Branch, Victoria, BC }\end{array}$ \\
\hline $\begin{array}{l}\text { National Fire Database } \\
\text { (NFD) }\end{array}$ & $\begin{array}{l}\text { Available for 1978-2005, source of forest } \\
\text { fire disturbances }\end{array}$ & $\begin{array}{l}\text { BC Forest Service, Protection Branch, Victoria, BC, } \\
\text { but also see Parisien et al. (2006) }\end{array}$ \\
\hline Landsat change & $\begin{array}{l}\text { Available for 1985-2008, used to fill known } \\
\text { spatial/temporal gaps in other data sources }\end{array}$ & Present study \\
\hline
\end{tabular}




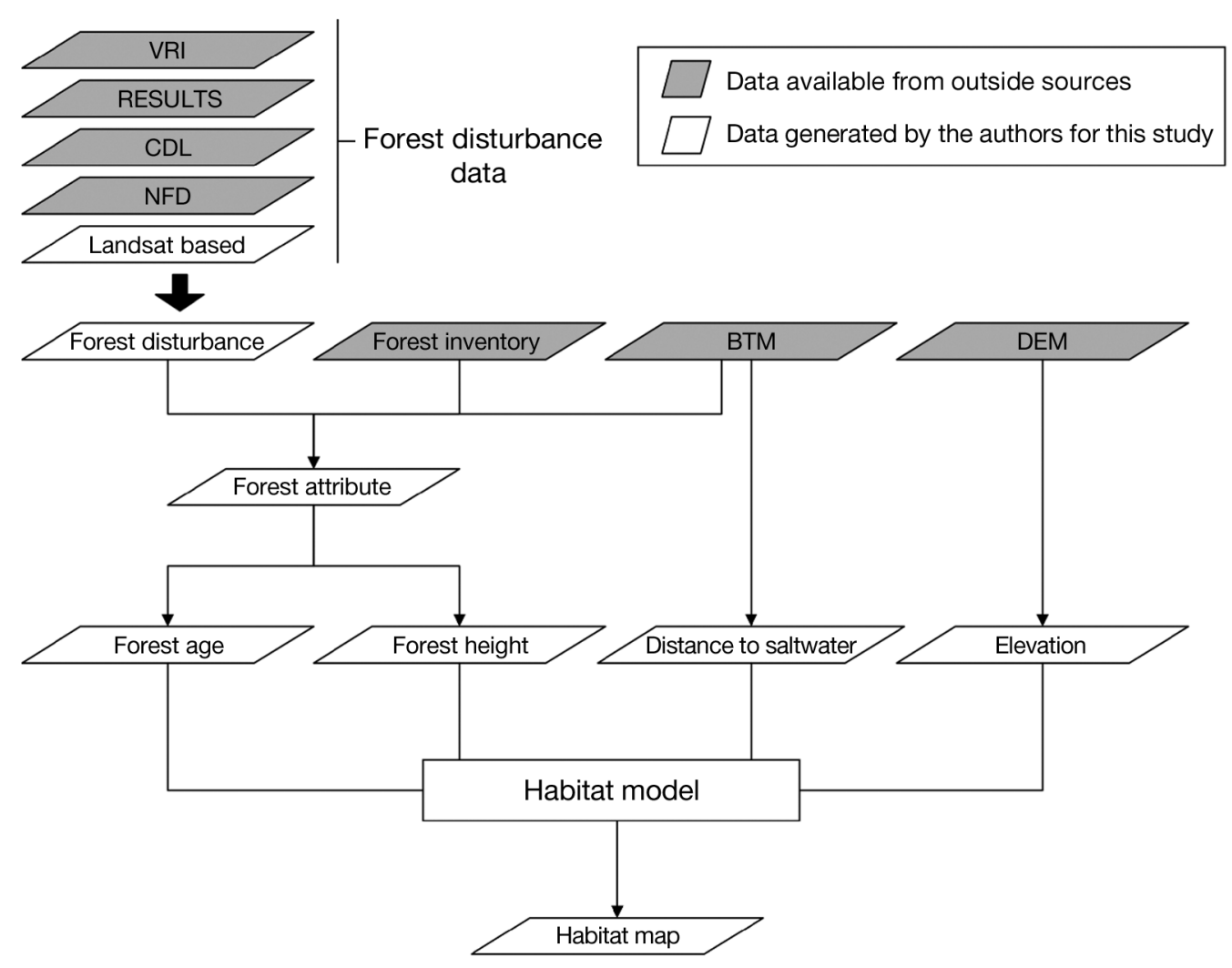

Fig. 2. Input data sources (see Table 2) are combined to generate datasets on environmental variables used in 3 marbled murrelet nesting habitat models. Abbreviations as in Table 2

tat lost between the first and second time periods (1978 and 2008). This approach does not consider increases to forest age and ignores the opportunity for new habitat to be recruited into potentially available classes over the study time period, in this case $30 \mathrm{yr}$. For instance, suitable habitat that was too young in 1978 crosses the model age threshold in 2008. In this example, recruitment of habitat is controversial as it represents the creation of new 'old-growth' forest. However, consideration of habitat recruitment is important as it preserves equivalent definitions of potential marbled murrelet habitat - from a data perspective - at both time points. We considered both types of analyses: habitat loss and net change in habitat, the latter including modelled habitat recruitment.

\section{RESULTS}

\section{Marbled murrelet nesting habitat models}

The predictive habitat models we implemented suggest that the spatial extent of potential marbled murrelet nesting habitat in 1978 covered 1.36 million to 4.70 million ha, depending on the model (Fig. 1, Table 3). The regional estimates of predicted marbled murrelet nesting habitat varied by model, with either the West and North Vancouver Island region or Central Coast region containing the largest amount of predicted nesting habitat (Table 3). The spatial extent of predicted marbled murrelet nesting habitat in 2008 ranged from 1.29 million to 4.03 million ha, with the intermediate Model 2 predicting 2.1 million ha of available marbled murrelet nesting habitat in 2008 (Fig. 1, Table 3).

\section{Marbled murrelet nesting habitat model loss}

We spatially detected a total of 1.06 million ha of forest disturbance (from harvest and fire) within the study area from 1978 to 2008 (Fig. 1). Forest fires accounted for less than $5 \%$ of all disturbance area, occurring primarily at substantial distances from the ocean shoreline, making fire a relatively minor disturbance factor in this analysis. By area, $26 \%$ of all disturbances intersected Model 1 habitat in 1978, 50\% intersected Model 2 habitat, and $73 \%$ intersected Model 3 habitat (Fig. 1, Table 3; 'Loss' column). Our estimates of marbled murrelet nesting habitat loss ranged from 16.3 to 20.6\%, (Fig. 1, Table 3). Models 1 and 2 showed very similar percentages of overall habitat loss, 20.2 and 
Table 3. Estimates of availability and changes to potential marbled murrelet nesting habitat in 1978 and 2008, using 3 habitat suitability models. Loss and recruitment represent negative and positive sources of change, respectively, to available habitat. Habitat loss is area of 1978 habitat that was lost by 2008 through forest disturbance. Habitat recruits from non-habitat in 1978 to Model 1 habitat in 2008 if, by aging for $30 \mathrm{yr}$, stand age crosses from $<250$ to $\geq 250 \mathrm{yr}$ and satisfies the other requirements of the model. Habitat recruits from non-habitat in 1978 to Model 2 (or Model 3) habitat in 2008 if, by aging for 30 yr, stand age crosses from $<140$ to $\geq 140 \mathrm{yr}$ and satisfies the other requirements of the model

\begin{tabular}{|c|c|c|c|c|c|c|c|}
\hline \multirow{2}{*}{$\begin{array}{l}\text { Model } \\
\text { Conservation region }\end{array}$} & \multicolumn{2}{|c|}{ Available habitat (ha) } & \multicolumn{2}{|c|}{ Loss } & \multirow{2}{*}{$\begin{array}{l}\text { Recruitment } \\
\text { (ha) }\end{array}$} & \multicolumn{2}{|c|}{ Net change } \\
\hline & 1978 & 2008 & ha & $(\%)$ & & (ha) & $(\%)$ \\
\hline \multicolumn{8}{|l|}{ Model 1} \\
\hline West \& North Vancouver Island & 442613 & 384579 & 113316 & $(25.6)$ & 55282 & -58034 & -13.1 \\
\hline East Vancouver Island & 32145 & 27005 & 5416 & $(16.8)$ & 276 & -5140 & -16.0 \\
\hline South Coast & 139346 & 114329 & 38422 & $(27.6)$ & 13405 & -25017 & -18.0 \\
\hline Central Coast & 298887 & 330384 & 64212 & $(21.5)$ & 95711 & +31497 & +10.5 \\
\hline North Coast & 228680 & 243404 & 18512 & $(8.1)$ & 33236 & +14724 & +6.4 \\
\hline Haida Gwaii & 221183 & 188933 & 35407 & $(16.0)$ & 3157 & -32250 & -14.6 \\
\hline Total & 1362854 & 1288634 & 275287 & $(20.2)$ & 201067 & -74220 & -5.4 \\
\hline \multicolumn{8}{|l|}{ Model 2} \\
\hline West \& North Vancouver Island & 808345 & 591019 & 225685 & $(27.9)$ & 8359 & -217326 & -26.9 \\
\hline East Vancouver Island & 125054 & 91882 & 33918 & $(27.1)$ & 746 & -33172 & -26.5 \\
\hline South Coast & 240394 & 200990 & 62438 & $(26.0)$ & 23034 & -39404 & -16.4 \\
\hline Central Coast & 630197 & 526622 & 112365 & $(17.8)$ & 8790 & -103575 & -16.4 \\
\hline North Coast & 475090 & 431566 & 52858 & $(11.1)$ & 9334 & -43524 & -9.2 \\
\hline Haida Gwaii & 310635 & 267859 & 45095 & $(14.5)$ & 2319 & -42776 & -13.8 \\
\hline Total & 2589715 & 2109938 & 532359 & $(20.6)$ & 52582 & -479777 & -18.5 \\
\hline \multicolumn{8}{|l|}{ Model 3} \\
\hline West \& North Vancouver Island & 1139886 & 846355 & 304271 & $(26.7)$ & 10740 & -293531 & -25.8 \\
\hline East Vancouver Island & 198840 & 151043 & 48657 & $(24.5)$ & 860 & -47797 & -24.0 \\
\hline South Coast & 566278 & 502973 & 98485 & $(17.4)$ & 35180 & -63305 & -11.2 \\
\hline Central Coast & 1253628 & 1105271 & 164345 & $(13.1)$ & 15988 & -148357 & -11.8 \\
\hline North Coast & 1033029 & 968185 & 85998 & $(8.3)$ & 21154 & -64844 & -6.3 \\
\hline Haida Gwaii & 512357 & 452934 & 66763 & $(13.0)$ & 7340 & -59423 & -11.6 \\
\hline Total & 4704018 & 4026761 & 7568519 & (16.3) & 91262 & -677257 & -14.4 \\
\hline
\end{tabular}

$20.6 \%$, respectively. Regionally, percent habitat loss using each of the 3 models was also similar, except for East Vancouver Island (16.8 to $27.1 \%$ ) and the South Coast (17.4 to $27.6 \%$; Table 3 ). Generally, estimated habitat loss was highest in the West and North Vancouver Island conservation regions, regardless of the model (25.6 to $27.9 \%)$. Predicted amounts of habitat loss were also high in the South Coast (17.4 to $27.6 \%$ ) and East Vancouver Island conservation regions (16.8 to $27.1 \%$ ), depending on the habitat model (Table 3 ).

\section{Marbled murrelet nesting habitat model recruitment}

Modelled habitat recruitment, based on forest aging over $30 \mathrm{yr}$, had a varied impact on model outputs (Fig. 1, Table 3; 'Recruitment' column). Models 2 and 3, both with thresholds for potentially suitable nesting habitat using $\geq 140$ yr forest age, had relatively similar estimates of modelled habitat recruitment, with $\sim 2 \%$ of the 2008 predicted available habitat resulting from modelled recruitment (52582 and 91262 ha, respectively; Table 3). Model 1, which was the most exclusive estimate of potential habitat with a forest age threshold for nesting habitat of $\geq 250 \mathrm{yr}$, had the most recruitment with $\sim 15 \%$ of the 2008 potential habitat resulting from recruitment (201 067 ha; Table 3). Regionally, Model 2 and Model 3 had different overall amounts of recruitment, but similar general patterns. For example, the highest (South Coast) and lowest (East Vancouver Island) amount of modelled habitat recruitment were the same for both models (Table 3).

\section{Marbled murrelet nesting habitat model change}

Throughout British Columbia, the percentage change in potential marbled murrelet nesting habitat, considering both habitat loss from harvest and fire and modelled habitat recruitment, varied from -5.4 to $-18.5 \%$ depending on the model (Table 3 ; 'Net change' column). Model 1, which had the most recruitment, showed the smallest amount of change $(-5.4 \%)$; Model 2 showed the most change $(-18.5 \%)$; Model 3 showed moderate change at $-14.4 \%$ (Table 3 ). Again, regional trends associated with change were variable 
across models. According to Model 1, the South Coast has had the greatest net loss in potential marbled murrelet nesting habitat (-18.0\%). For Models 2 and 3, net loss was greatest in West and North Vancouver Island (-26.9 and $-25.8 \%$ ) followed by East Vancouver Island (-26.5 and $-24.0 \%$; Table 3).

\section{DISCUSSION}

We used GIS and habitat suitability modelling to derive estimates of potential marbled murrelet habitat, habitat loss due to harvest and fire, and net change of potential marbled murrelet habitat from 1978 to 2008, which included estimates of habitat recruitment.

Our modelled 2008 estimates of potentially suitable habitat for nesting marbled murrelets in British Columbia were similar to other range-wide binary habitat suitability studies (e.g. Mather et al. 2010). In particular, our estimate of overall 2008 Model 2 potential nesting habitat (2 109938 ha) was very close to an estimate from an earlier modelling study that used the same parameter set, but some different data sources and methods (1980 846 ha; Mather et al. 2010). The minor differences in the 2 estimates are most likely due to the data sources; for example, we used Landsat-based change data as opposed to forest inventory data for most of the coast to estimate disturbance (Mather et al. 2010). However, the $\sim 6 \%$ difference in the 2 potential habitat availability estimates was largely due to different estimates for the Haida Gwaii and West and North Vancouver Island conservation regions, with our predicted estimates much higher for these regions (Mather et al. 2010, present study). These differences may result from specific variations in model implementation for these 2 regions, as Mather et al. (2010) substituted their coast-wide algorithm with a local model in the Clayoquot Sound area of West Vancouver Island (Bahn \& Newsom 2002) and aerial photo interpretation data in Haida Gwaii (Waterhouse et al. 2009, 2010, Burger et al. 2009).

Forest disturbances had the largest impact on Model 2 potential habitat $(20.6 \%$ loss $)$. Considering the coastwide scale of the analysis, the estimates of habitat loss were relatively similar across all 3 models. However, estimates of modelled habitat recruitment, and resulting net change in available habitat, varied considerably among models (Table 3). The high level of estimated habitat recruitment in Model 1 is most likely an artefact of the limitations of the forest inventory data (Waterhouse et al. 2010), in conjunction with the most exclusive definition of potentially suitable nesting habitat (CMMRT 2003). In mature forests, age class midpoints were frequently adopted due to difficulty interpreting exact ages, leading to clustering in the for- est age class frequency distribution (Wong et al. 2003). The high levels of recruitment in Model 1 are likely an artefact of an age class cluster going from $<250 \mathrm{yr}$ in 1978 to $\geq 250$ yr in 2008, as opposed to an actual estimate of biologically meaningful nesting habitat recruitment (CMMRT 2003). In general, any estimate of recruitment of potential marbled murrelet nesting habitat over relatively short time scales (e.g. 30 yr) should be considered with caution, as the attributes that 'recruit' through time (e.g. forest age) are simply surrogates based on limited datasets (Waterhouse et al. 2010). In the case of potential marbled murrelet nesting habitat, it is unlikely that the platform characteristics associated with older forests and necessary for marbled murrelet nesting, such as moss-covered branches, 'recruit' within relatively short time frames (CMMRT 2003, Burger et al. 2010). However, this same caution should be applied to single time-frame habitat models, such as our 1978 models. In this case, habitat was deemed suitable by forest stand age or height class; however, some of the identified stands are unlikely to contain the necessary platform characteristics (e.g. forest stand age $251 \mathrm{yr}$ ). Thus, excluding considerations of 'recruitment' habitat in the latter time span of change analyses only could lead to a biased interpretation of habitat loss or change.

Our detection of forest disturbances from harvest and fires was limited by the availability of spatial data sets. For example, our forest disturbance data capture only clear-cut type harvesting. Other harvesting practices, such as partial-retention harvesting, can similarly impact potential murrelet nesting habitat. However, throughout our study area the amount of partial-retention type harvesting is relatively small when compared to the level of clear-cut harvest (British Columbia Ministry of Forests and Range 2010). Forest harvests of $<1$ ha were not captured within 2 of the forest disturbance change layers (our Landsatbased layer, and the change detection layer, Table 2). Complete spatial harvest data for 1978 to 1985 were also lacking (see 'Materials and methods'). To investigate the effect of limited spatial data from 1978 to 1985, we can compare our spatial forest disturbance data with aspatial harvest reporting records in the Ministry of Forests and Range's Annual Reports (British Columbia Ministry of Forests 1979-1986). Our spatial estimates of forest disturbance from 1985 to 2008 (where our data are most complete) align well with documented aspatial harvesting records, suggesting that our disturbance layer is relatively robust and that the missing $<1$ ha disturbances may be negligible relative to the scale of this analysis.

Given the known deficiency in our data from 1978 to 1985, an option for mitigating this effect is to supplement our estimates using aspatial harvest information 
from the annual reports. For example, the total area harvested over our study region from 1978 to 1985, according to the annual reports, was approximately 366000 ha. This number was generated by adding harvest records from the Vancouver Forest region and the Prince Rupert Forest region, with totals for the Prince Rupert Forest region scaled by 0.44 to reflect the proportion of our study area that fell within this forest region, and assumes no spatial bias of harvests in this region. Using the spatial forest harvest data for 1978 to 1985 (Table 2), 176000 ha of harvest were spatially detected during this time period and thus already considered in our spatial analyses. Therefore, an additional 190000 ha of forest loss due to harvest occurred from 1978 to 1985 that we did not detect because of limited spatial data over this time frame. If we assume the same disturbance proportions for the 190000 ha forest disturbances within each habitat model as other disturbances (Model 1: $26 \%$, Model 2: $50 \%$, Model 3: $73 \%$; see 'Results'), then our adjusted estimates of potential nesting habitat loss would be 19 to $24 \%$, depending on model, or -9 to $-22 \%$ net change in potential nesting habitat if modelled recruitment is considered. These adjusted estimates are likely closer to the actual degree of potential marbled murrelet nesting habitat loss, although this type of aspatial adjustment includes numerous assumptions.

Our results are based on a set of potential marbled murrelet nesting habitat models, ranging from exclusive to inclusive definitions of potential nesting habitat; however, all 3 models applied are appropriate for broad-scale and strategic planning (e.g. Burger et al. 2005, Mather et al. 2010, Waterhouse et al. 2010). Model 2, which is based on the intermediate parameter set of Mather et al. (2010), performed well in the North Coast conservation region when tested against lowlevel aerial habitat surveys, with $99 \%$ of sites (84/85) modelled as habitat containing some marbled murrelet habitat attributes (Burger et al. 2005). However, Model 2 was found to underestimate habitat suitability when compared to aerial photo assessment methods in other regions of the coast (Waterhouse et al. 2010). The model of Mather et al. (2010) has been selected by the CMMRT as the baseline for monitoring the relative abundance of potential marbled murrelet nesting habitat in British Columbia through time.

Our $30 \mathrm{yr}$, province-wide spatial analyses and corrected estimates of potential marbled murrelet habitat loss, based on Model 2 (20.6 and 24\%, respectively) and Model 3 (16.3 and 20\%, respectively), were similar to values reported in previous regional or shorter timeframe analyses of marbled murrelet nesting habitat change in British Columbia. The British Columbia Ministry of Forests estimated that approximately $24 \%$ of potential marbled murrelet nesting habitat had been harvested from 1973 to 2000, based on BTM data (M. Eng pers. comm.). M. Tomlins \& M. Gray (unpubl.) reported an $18.3 \%$ loss of potential marbled murrelet nesting habitat from 1985 to 2005 in the Sunshine Coast Forest District of British Columbia, with a $12 \%$ net loss, when offsetting for recruitment of nesting habitat over the same time period is considered. Finally, the Gowgaia Institute (2007) estimated that 92776 ha (31 474 ha from 1978 to 1985; 61302 ha from 1985 to 2008) of forests were logged on Haida Gwaii from 1978 to 2008, based on their high spatial-temporal resolution harvest dataset for the region. Our spatial analysis revealed forest disturbance for Haida Gwaii covering 67203 ha (9183 ha from 1978 to 1985; 58020 ha from 1985 to 2008). While our forest disturbance data underestimate disturbance area when compared to high-resolution imagery, the majority of the underestimation occurred expectedly between 1978 and 1985, due to missing spatial harvest records. However, we adjusted for the missing spatial data coast-wide by using an aspatial estimate of additional forest disturbance from 1978 and 1985. Our adjusted coast-wide estimate is likely more robust, regardless of model choice.

Our estimates of potential murrelet habitat and subsequent habitat loss and change are influenced by uncertainty (e.g. upward or downward biases), such as actual suitability of forest stands for breeding murrelets (e.g. presence of suitable limbs for nesting) and known deficiencies in the forest harvest spatial datasets. In our study, Models 2 and 3 produced similar estimates of potential nesting habitat loss and change, and we feel that these 2 models and associated analyses provide a realistic range of potential habitat loss and net change scenarios in British Columbia over the past $30 \mathrm{yr}$. These results provide the first provincewide habitat change scenarios and are consistent with previous regional analyses of potential marbled murrelet habitat loss in British Columbia.

\section{CONCLUSIONS}

Based on our intermediate and inclusive habitat models, with the aspatial adjustment included, we estimate that 20 to $24 \%$ of potential marbled murrelet nesting habitat has been lost to forest harvest and fire from 1978 to 2008. If modelled recruitment is considered, then net change in potential nesting habitat would be 20 to $22 \%$ loss. The potential marbled murrelet nesting habitat models and our resulting disturbance and change estimates presented here are intended to support strategic land use decisions and monitoring of the status of this wide-ranging species (CMMRT 2003, Steventon et al. 2003, Burger \& Water- 
house 2009, Waterhouse et al. 2010). Given the paucity of data on population trends of marbled murrelets in British Columbia, these $30 \mathrm{yr}$ changes in terrestrial habitat data are particularly informative for re-occurring assessments of the conservation status of this high-profile species in Canada (COSEWIC 2000).

Broad- and regional-scale modelling of habitat is important for management and provides an approach for monitoring wildlife when population and occurrence data are unavailable (e.g. Berland et al. 2008, Mather et al. 2010, Waterhouse et al. 2010). As with all large-area models, we recommend using our results for strategic planning, and suggest using finer-scaled data products, such as aerial photo interpretation habitat inventories (e.g. Waterhouse et al. 2008, Burger et al. 2009), for tactical planning (e.g. placement of protection or management guidelines, Waterhouse et al. 2010). For future work on coast-wide assessments of potential marbled murrelet habitat changes, we suggest that a closer examination of the spatial patterns of change and loss in nesting habitat (e.g. edges, patch size, and connectivity) may be valuable, as harvesting may actually impact the suitability of nesting habitat in the surrounding intact forest (e.g. Burger 2002, Piatt et al. 2007, Malt \& Lank 2007, 2009).

Acknowledgements. Funding for this work was provided by the Fraser Basin Council. Additional support was provided by the Natural Sciences Engineering Research Council of Canada (NSERC) and the Species at Risk Coordination Office, British Columbia Ministry of Environment. T. Edghill and M. Tomlins assisted with data preparation. N. Gralewicz assisted with data preparation and figures. Thanks to A. Morrison for access to, and information on, harvest change data for British Columbia. We appreciate the valuable feedback from M. Eng, M. Gray, D. Fraser, L. Darling, A. Burger, L. Waterhouse, and C. Pasztor at various stages of this project. Helpful comments from the reviewers and the editor greatly improved this manuscript. The interpretations presented in this paper are those of the authors, and not their respective organisations.

\section{LITERATURE CITED}

Bahn V, Newsom D (2002) Habitat suitability mapping for marbled murrelets in Clayoquot Sound. In: Burger AE, Chatwin TA (eds) Multi-scale studies of populations, distribution and habitat associations of marbled murrelets in Clayoquot Sound, British Columbia. British Columbia Ministry of Water, Land and Air Protection, Victoria, BC, p 101-119. Available at http://env.gov.bc.ca/wld/documents/ techpub/mamuwebs.pdf (accessed June 2010)

Becker BH, Beissinger SR (2006) Centennial decline in the trophic level of an endangered seabird after fisheries decline. Conserv Biol 20:470-479

- Becker BH, Peery MZ, Beissinger SR (2007) Ocean climate and prey availability affect the trophic level and reproductive success of the marbled murrelet, an endangered seabird. Mar Ecol Prog Ser 329:267-279
Beissinger SR, Peery MZ (2007) Reconstructing the historic demography of an endangered seabird. Ecology 88: 296-305

Berland A, Nelson TA, Stenhouse G, Graham K, Cranston J (2008) The impact of landscape disturbance on grizzly bear habitat use in the Foothills Model Forest, Alberta, Canada. For Ecol Manag 256:1875-1883

Bertram DF, Burger AE, Lindsay D, Cober A, Harfenist A (2007) Marbled murrelet population estimation and trend monitoring in BC. Pacific Seabird Group 34th Annual Meeting, Asilomar, CA. February 2007. Available at www. pacificseabirdgroup.org/downloads/PSG2007_Abstracts. pdf (accessed June 2010)

British Columbia Ministry of Environment, Lands and Parks (1995) Baseline thematic mapping: present land use mapping at 1:250000. Content Series Vol 6, Part 1. British Columbia Ministry of Environment, Lands and Parks, Surveys and Resource Mapping Branch, Victoria, BC

British Columbia Ministry of Forests (1979-1986) Annual reports of the British Columbia Forest Service for the years 1978-1985. Available at www.for.gov.bc.ca/hfd/ pubs/docs/mr/annual/annualrpt.htm (accessed June 2010)

British Columbia Ministry of Forests and Range (2010) Silviculture program statistics: annual reports of silviculture investments and accomplishments. Available at www.for. gov.bc.ca/hfp/silviculture/statistics/statistics.htm (accessed December 2010)

British Columbia Ministry of Sustainable Resource Management (2002) Gridded digital elevation model product specifications. British Columbia Ministry of Sustainable Resource Management, Base Mapping and Geomatics Services Branch, Victoria, BC

Burger AE (2001) Using radar to estimate populations and assess habitat associations of marbled murrelets. J Wildl Manag 65:696-715

Burger AE (2002) Conservation assessment of marbled murrelets in British Columbia: a review of the biology, populations, habitat associations, and conservation. Tech Rep Ser, No. 387. Canadian Wildlife Service, Pacific and Yukon Region, Delta, British Columbia. Available at www.sfu.ca/biology/wildberg/bertram/mamurt/PartA.pdf (accessed June 2010)

Burger AE, Waterhouse FL (2009) Relationships between habitat area, habitat quality, and populations of nesting marbled murrelets. BC J Ecosyst Manag 10:101-112. Available at www.forrex.org/publications/jem/ISS50/ vol10_no1_art10.pdf

Burger AE, Hobbs J, Hetherington A (2005) Testing models of habitat suitability for nesting marbled murrelets, using low-level aerial surveys on the north coast, British Columbia. Report to Ministry of Water, Land and Air Protection, Smithers. Available at http://web.uvic.ca/ mamu/pdf/ Burger\%20et\%20al.\%20NC\%20Heli\%202005\%20Report. pdf (accessed June 2010)

Burger AE, Waterhouse FL, Donaldson A, Whittaker C, Lank DB (2009) New methods for assessing marbled murrelet nesting habitat: air photo interpretation and low-level aerial surveys. BC J Ecosyst Manag 10:4-14

> Burger AE, Ronconi RA, Silvergieter MP, Conroy C and others (2010) Factors affecting the availability of thick epiphyte mats and other potential nest platforms for marbled murrelets in British Columbia. Can J For Res 40:727-746

Chatwin T, Mather M (2007) Background document to accompany BC marbled murrelet habitat suitability maps. Available at www.forrex.org/program/con_bio/ pdf/workshops/mamu/Backgrnd_and_Maps.pdf (accessed June 2010) 
CMMRT (Canadian Marbled Murrelet Recovery Team) (2003) Marbled murrelet conservation assessment 2003, Part B: Marbled murrelet recovery team advisory document on conservation and management. Canadian Marbled Murrelet Recovery Team Working Document No. 1. Available at www.sfu.ca/biology/wildberg/bertram/ mamurt/PartB.pdf (accessed June 2010)

COSEWIC (Committee on the Status of Endangered Wildlife in Canada) (2000) COSEWIC assessment and status report on the marbled murrelet Brachyramphus marmoratus in Canada. COSEWIC, Ottawa. Available at www.cosewic. gc.ca/ (accessed June 2010)

Franklin SE, Lavigne MB, Moskal LM, Wulder MA, McCaffrey TM (2001) Interpretation of forest harvest conditions in New Brunswick using Landsat TM enhanced wetness difference imagery (EWDI). Can J Rem Sens 27:118-128

Franklin SE, Lavigne MB, Wulder MA, McCaffrey TM (2002) Large-area forest structure change detection: an example. Can J Rem Sens 28:588-592

Gowgaia Institute (2007) Forest economy trends and economic conditions on Haida Gwaii. Gowgaia Institute, Queen Charlotte, BC. Available at www.spruceroots.org/ Booklets/ForTrends.pdf (accessed June 2010)

Gutowsky S, Janssen MH, Arcese P, Kyser TK and others (2009) Concurrent declines in nestling diet quality and reproductive success of a threatened seabird over 150 years. Endang Species Res 9:247-254

Hull CL, Kaiser GW, Lougheed C, Lougheed L, Boyd S, Cooke $F$ (2001) Intraspecific variation in commuting distance of marbled murrelet (Brachyramphus marmoratus): ecological and energetic consequences of nesting further inland. Auk 118:1036-1046

IUCN Standards and Petitions Subcommittee (2010) Guidelines for using the IUCN Red List categories and criteria. Version 8.1. Available at http://intranet.iucn.org/webfiles/ doc/SSC/RedList/RedListGuidelines.pdf (accessed June 2010)

Kelson JD, Manley IA, Carter HR (1995) Decline of the marbled murrelet in Clayoquot Sound, British Columbia: 1982-1993. Northwest Nat 76:90-98

Lank DB, Parker NP, Krebs EA, McFarlane Tranquilla L (2003) Geographic distribution, habitat selection, and population dynamics with respect to nesting habitat characteristics of marbled murrelets Brachyramphus marmoratus. Centre for Wildlife Ecology, Simon Fraser University, Burnaby. Available at www.sfu.ca/biology/wildberg/ MaMuLiteraturereview.3.pdf (accessed June 2010)

Leckie D, Gillis M (1995) Forest inventory in Canada with emphasis on map production. For Chron 71:74-88

Malt JM, Lank DB (2007) Temporal dynamics of edge effects on nest predation risk for the marbled murrelet. Biol Conserv 140:160-173

Malt JM, Lank DB (2009) Marbled murrelet nest predation risk in managed forest landscapes: dynamic fragmentation effects at multiple scales. Ecol Appl 19:1274-1287

Mather M, Chatwin T, Cragg J, Sinclair L, Bertram DF (2010) Marbled murrelet nesting habitat suitability model for the British Columbia coast. BC J Ecosyst Manag 11:91-102. Available at http://jem.forrex.org/index.php/jem/article/ view/11/27

McLennan D, Veenstra V, Manley I (2000) Preliminary land- scape-level habitat suitability algorithms for marbled murrelet and Queen Charlotte goshawk on the Queen Charlottes Islands/Haida Gwaii. Report to Ministry of Environment, Lands and Parks, Smithers, BC. Oikos Ecological Services, Smithers. Available at www.for.gov.bc.ca/hfd/library/ documents/bib88462.pdf (accessed June 2010)

> Norris DR, Arcese P, Preikshot D, Bertram DF, Kyser TK (2007) Diet reconstruction and historic population dynamics in a threatened seabird. J Appl Ecol 44:875-884

Parisien MA, Peters VS, Wang Y, Little JM (2006) Spatial patterns of forest fires in Canada, 1980-1999. Int J Wildland Fire 15:361-374

Piatt JF, Kuletz KJ, Burger AE, Hatch SA and others (2007) Status review of the marbled murrelet (Brachyramphus marmoratus) in Alaska and British Columbia: US Geological Survey Open-File Report 2006-1387. Available at http://pubs.usgs.gov/of/2006/1387/ (accessed June 2010)

Province of British Columbia (1996) Gridded DEM specifications. Ministry of Sustainable Resource Management, Victoria, BC

Raphael MG, Evans MD, Cooper BA (2002) Landscape-scale relationships between abundance of marbled murrelets and distribution of nesting habitat. Condor 104:331-332

Ryan MG, Yoder BJ (1997) Hydraulic limits to tree height and tree growth. Bioscience 47:235-242

Sandvoss M, McClymont B, Farnden C (2005) A user's guide to the vegetation resources inventory. Timberline Forest Inventory Consultants. Tolko Industries, Williams Lake

Steventon JD, Sutherland GD, Arcese P (2003) Long-term risks to marbled murrelet (Brachyramphus marmoratus) populations: assessing alternative forest management policies in coastal British Columbia. Tech Rep 012. Research Branch, British Columbia Ministry of Forests, Victoria, BC. Available at www.for.gov.bc.ca/hfd/pubs/ Docs/Tr/Tr012.htm (accessed June 2010)

Waterhouse FL, Donaldson A, Lank DB, Ott PK, Krebs EA (2008) Using air photos to interpret quality of marbled murrelet nesting habitat in south coastal British Columbia. BC J Ecosyst Manag 9:17-37. Available at www.forrex. org/publications/jem/ISS47/vol9_no1_art3.pdf

Waterhouse FL, Burger AE, Lank DB, Ott PK, Krebs EA, Parker N (2009) Using the low-level aerial survey method to identify marbled murrelet nesting habitat. BC J Ecosyst Manag 10:80-96. Available at www.forrex.org/ publications/jem/ISS50/vol10_no1_art8.pdf

Waterhouse FL, Burger AE, Ott PK, Donaldson A, Lank DB (2010) Does interpretation of marbled murrelet nesting habitat change with different classification methods? BC J Ecosyst Manag 10:20-34. Available at www.forrex.org/ publications/jem/ISS52/vol10_no3_art4.pdf

Wong C, Dorner B, Sandmann H (2003). Estimating historical variability of natural disturbances in British Columbia. Land Management Handbook No. 53. British Columbia Ministry of Forests Research Branch, British Columbia Ministry of Sustainable Resource Management, Resource and Planning Branch, Victoria, BC

Yen PPW, Huettmann F, Cooke F (2004) A large-scale model for the at-sea distribution and abundance of marbled murrelets (Brachyramphus marmoratus) during the breeding season in coastal British Columbia, Canada. Ecol Model 171:395-413

Submitted: July 29, 2010; Accepted: February 10, 2011

Proofs received from author(s): April 22, 2011
Editorial responsibility: Rory Wilson,

Swansea, UK 